\title{
Modelling the Thin-Layer Drying Kinetics of Untreated and Blanch- Osmotic Pre-treated Tomato Slices
}

\author{
Samuel Enahoro Agarry* \\ Biochemical and Bioenvironmental Engineering Laboratory, Department of Chemical Engineering, Delta State University, Abraka, P.M.B. \\ 22, Oleh Campus, Nigeria

\section{A R T I C LE IN F O} \\ Article history: \\ Received 04 May 2016 \\ Accepted 22 September 2016 \\ Available online, ISSN: 2148-127X \\ Keywords: \\ Tomato \\ Blanching \\ Osmotic dehydration \\ Drying models \\ Diffusivity \\ Vitamin C \\ Corresponding Author: \\ E-mail: sam_agarry@yahoo.com

\begin{abstract}
A B S T R A C T
The objective of this study was to investigate the effect of pre-treatment and drying esculantum L.) under hot air drying. Tomato samples were blanched at $80^{\circ} \mathrm{C}$ and osmotically dehydrated using $20 \% \mathrm{w} / \mathrm{w}$ sodium chloride solutions at $30^{\circ} \mathrm{C}$ for $20 \mathrm{~min}$. The blanch-osmotic pre-treated and untreated tomato slices were dried at temperature of $40,50,60,70$ and $80^{\circ} \mathrm{C}$, respectively in a hot air-dryer. The results showed that blanchosmotic pre-treatment offered a higher drying rate and lower or faster drying time than untreated condition. The tomato drying regime was characteristically in the constant and falling rate period. The tomato drying rate curve showed characteristics of porous hygroscopic solids. The optimum drying temperature for tomato was found to be $60^{\circ} \mathrm{C}$. Four semi-empirical drying models of Newton, Page, Henderson and Pabis, and Logarithmic were fitted to the drying data using non-linear regression analysis. The most appropriate model was selected using the coefficient of determination $\left(R^{2}\right)$ and root mean square error $(R M S E)$. The Page model has shown a better fit to the drying kinetics data of tomato in comparison with other tested models. Transport of moisture during drying was described by Fick's diffusion model application and the effective moisture diffusivity $\left(D_{e f f}\right)$ thus estimated. The $D_{\text {eff }}$ at $60^{\circ} \mathrm{C}$ was $4.43 \times 10^{-11} \mathrm{~m}^{2} / \mathrm{s}$ and $6.33 \times 10^{-11} \mathrm{~m}^{2} / \mathrm{s}$ for blanch-osmotic pre-treated and untreated tomato slices, respectively.
\end{abstract} \\ temperature on the drying kinetics and nutritional quality of tomato (Lycopersicon
}

\section{Introduction}

Tomato being a rich source of vitamins and minerals is one of the most important vegetables grown worldwide on a variety of soil and climatic condition (Sacilik, 2007). They are one of the world's most traded vegetable in both fresh and processed forms (such as ketchup, sauces, pastes, juice and dried products). More than 100 million tonnes of tomato are produced in the world and United State of America, China, Turkey, Italy, and Spain are the leading tomato growing countries (Sacilik, 2007). However, being highly perishable in the fresh state leading to wastage and losses, it requires preservation in some form.

Drying technology has been one of the oldest technologies and of great antiquity used in the preservation of food materials. It is gaining more attention as one of the emerging technologies that require innovations for research studies (Agarry and Aworanti, 2012). There are a lot of drying methods, however, hot air-drying method has been one of the simple common methods used for fruits and vegetables (Ando et al., 2013). In hot air drying equipment, drying is an energy intensive unit operation (Dandamrongrak et al., 2003) driven by a number of factors such as humidity, temperature and velocity. Long drying periods tend to increase the energy requirements for the production of a unit dry product and may as well lead to poor quality of final product (Dandamrongrak et al., 2003; Agarry et al., 2013). The process conditions of drying that could result in the reduction of drying period are sought after so as to give rise to an acceptable final products that are economically and nutritionally viable (Agarry and Aworanti, 2012).

It is on this fundamental principle that in recent times, there have been several studies on the effect of physical pre-treatment such as high hydrostatic pressure (VegaGalvez et al., 2012), blanching, freezing and osmotic pretreatment (Sankat et al., 1996; Nieto et al., 2001; Dandamrongrak et al., 2003; Kingsly et al., 2007; Agarry and Aworanti, 2012; Ando et al., 2013; Akonor and Tortoe, 2014; Afolabi et al., 2015) as well as chemical pre-treatment such as soaking in potassium and sodium hydroxide, potassium meta bisulphate, sodium meta bisulphate, potassium carbonate, methyl and ethyl ester emulsions, ascorbic and citric acids (Doymaz, 2004; Kingsly et al. 2007; Doymaz, 2010; Vega-Galvez et al., 2012; Afolabi et al., 2015) prior to convective drying on the drying kinetics of fruit and vegetables. These studies have revealed that pre-treatments increase the rate of drying and thereby reduce the period of drying. However, non-chemical forms of pre-treatment are generally 
preferred especially among small-scale processors in the tropical region (Tunde-Akintunde and Ogunlakin, 2013).

Blanching is an important step in the processing of food such that it helps in the inactivation of enzymes (Ando et al., 2013; Agarry et al., 2013), changes in tissue structure (Gupta et al., 2014) and has also been observed to increase drying rate and consequently reduce the drying time of some food materials like carrots, pineapple, red pepper, aonla, broccoli, etcetera (Ando et al., 2013; Agarry et al., 2013; Gupta et al., 2014; Doymaz, 2014). While in some cases it has been found not to have significant effect on the drying rate and drying time of some food materials such as potato and avocado (Alzamora and Chirife, 1980; Agarry et al., 2005). However, combination of blanching and freezing (Dandamrongrak et al., 2003) as well as the combination of blanching and chemical pre-treatment (Gupta et al., 2014) have been reported to result in increased drying rate and reduced drying period. Furthermore, osmotic pretreatment has been observed to offer beneficial effects, some of which includes higher quality of the final product and lower energy requirements (Ozen et al., 2002). Although there has been some literature on drying of tomato (Doymaz, 2007; Sacilik, 2007; Purkayastha et al., 2013), nevertheless, studies on the effect of the combination of blanching and osmotic pre-treatment on the hot air drying characteristics of tomato is rarely scarce and also the selection of appropriate drying model to describe the drying behaviour for the variety common in the country and within the experimental conditions considered in this study is yet to be done.

Therefore, the main objective of this study was to investigate the effect of blanch-osmotic pre-treatment on the hot air drying of ripe tomato and to model the dry kinetics using some known semi-empirical drying models in the literature. The effect of drying temperatures on the nutritional value of the dried tomato products was also studied for determining the optimum drying temperature that might produce high-quality dried tomato products.

\section{Materials and Methods}

The tomato samples used for this study were obtained from a local market in Oleh, Delta State, Nigeria. Salt (sodium chloride) of analytical grade (BDH) was used as the osmotic agent (solute) for the osmotic pretreatment. The other materials used in this study include beakers, electronic weighing balance, temperature controlled water bath and cabinet dryer.

\section{Blanching - Osmotic Pretreatment}

Fresh, ripe and firm tomatoes were thoroughly washed and introduced inside a beaker that contained water. It was then placed in a temperature controlled water bath (DK-420 Glufex Medical and Scientific, England) and heated at $80^{\circ} \mathrm{C}$ for $1 \mathrm{~min}$ and thereafter quickly immersed in cold water. The blanched tomatoes were blotted dry using absorbent paper to remove excess water. The blanched tomatoes were then cut into small pieces of about $5 \mathrm{~mm}$ in diameter. Sixty gram $(60 \mathrm{~g})$ of blanched tomato slices were placed in a $250 \mathrm{ml}$ beaker containing sodium chloride (salt) solution of concentration $20 \% \mathrm{w} / \mathrm{w}$. The beaker was then placed in a temperature controlled water bath maintained at $30^{\circ} \mathrm{C}$ for 30 minutes. Thereafter, the osmotic dehydrated samples of blanched tomato slices were removed and the excess solution on the surface of samples was removed with absorbent paper and then reweighed.

\section{Untreated Sample}

Fresh, ripe and firm tomatoes were thoroughly washed and then cut into small pieces of about $5 \mathrm{~mm}$ in diameter, weighed and charged onto drying trays without pretreatment.

\section{Hot Air-Drying}

The drying tests were carried out in a fabricated cabinet (tray) dryer in the Biochemical and Bioenvironmental Engineering Laboratory of the Department of Chemical Engineering, Delta State University, Abraka, Oleh Campus, Nigeria. The dimensions of the dryer are $0.693 \times 0.470 \times 0.486 \mathrm{~m}$. The dryer consisted of four layers of tray, electrical heater, fan and a temperature controller $\left(30-200^{\circ} \mathrm{C}\right.$, dry bulb temperature). The blanch-osmotic pre-treated tomato slices were arranged within an area of $1.45 \mathrm{~m}^{2}$ on the tray of the cabinet dryer and drying was performed at a dry bulb temperature of $40^{\circ} \mathrm{C}$. At regular time intervals of $2 \mathrm{~h}$, the samples were withdrawn and allowed to cool in a desiccator after which the weight was measured. The total drying time was taken as the time required for the sample to attain a constant weight (or bone dry weight). Drying rates were estimated based on the product of change in moisture content and weight of dry solid per unit time and cross-sectional area of tray $\left(\mathrm{kg} \mathrm{m}^{-2} \mathrm{~h}^{-1}\right)$ (Agarry et al., 2006). The moisture contents of both the fresh and dried samples were determined according to AOAC (1995). The same procedure was repeated for drying temperatures of $50^{\circ} \mathrm{C}, 60^{\circ} \mathrm{C}, 70^{\circ} \mathrm{C}$ and $80^{\circ} \mathrm{C}$, respectively. Also, the untreated sliced tomato samples were dried at 40, 50, 60, 70 and $80^{\circ} \mathrm{C}$, respectively.

\section{Determination of Ascorbic Acid}

The ascorbic acid content of both the fresh and dried tomato samples was determined using the 2, 6dichlorophenol indophenol dye titration method (Rangana, 1986).

\section{Mathematical Modeling}

Mathematical modelling is an essential tool to predict and simulate the drying behaviour of food materials. It is also an important tool in the design of drying equipment, contributing to a better understanding of the drying mechanism. Mathematical drying models describe the drying phenomenon regardless of the controlling mechanisms (Kingsly et al., 2007; Agarry and Aworanti, 2012). In thin layer drying, the moisture ratio can be calculated according to Eq. (1):

$$
M R=\frac{M-M_{e}}{M-M_{e}}
$$


Where $M R$ is the dimensionless moisture ratio, $M$, the average moisture content at time $t, M_{0}$, the initial moisture content, and $M_{e}$, the equilibrium moisture content respectively, on a dry weight basis.

During the thin layer drying of tomato in the tray dryer, the samples were not continuously exposed to uniform temperature and relative humidity. As a result of this, the equilibrium moisture content could not be determined and this is usually not high for food materials (Waewsak et al., 2006; Agarry et al., 2013), hence, the equilibrium moisture content was assumed to be zero. Thus, the moisture ratio (Eq. (1)) was simplified according to Kingsly et al. (2007) to:

$$
M R=\frac{M}{M_{0}}
$$

The recorded moisture contents for tomato vegetable sample were then used to plot the drying curves. Four known semi-empirical mathematical drying models that expresses relationship between moisture ratio $(M R)$ and the drying time, $t$ as presented in Eqs. (3) to (6) were fitted or applied to the drying curves obtained for the tomato sample at drying temperature of $60^{\circ} \mathrm{C}$.

$\begin{array}{ll}\text { Newton } & M R=\exp (-k t) \\ \text { Page } & M R=\exp \left(-k t^{n}\right) \\ \text { Henderson \& Pabis } & M R=\mathrm{a} \exp (-k t) \\ \text { Logarithmic } & M R=\mathrm{a} \exp (-k t)+c\end{array}$

Where $a, c, n$ are empirical constants; $k$, drying constant; and $t$, drying time. The non-linear regression analysis tool in MATLAB computer software package (version 7.0) was used for the fit. Some of these models have been recently used for determination of moisture ratio with drying time by Ismail and Ibn Idriss (2013) and Khawas et al. (2014). The coefficient of determination $\left(R^{2}\right)$ and root mean square error (RMSE) were major criteria for selection of the best model equation to describe the drying curve. For quality fit, $\left(R^{2}\right)$ value should be high and RMSE should be low (Demir et al., 2004). In order to evaluate the goodness of fit of the simulation provided by the proposed (best selected) model, different statistical parameters are usually used. In this study, the average relative error (Eq. (7)) and root mean square error (Eq. (8)) (Simal et al., 2005; Agarry et al., 2013) were calculated.

$$
\begin{aligned}
& \% E=\frac{100}{N} \sum_{i=1}^{N}\left[M R_{\exp _{i}}-M R_{\text {pre }_{i}} / M R_{\exp _{i}}\right] \\
& R M S E=\left[\frac{1}{N} \sum_{i=1}^{N}\left(M R_{\exp _{i}}-M R_{\text {pre }_{i}}\right)^{2}\right]^{1 / 2}
\end{aligned}
$$

Where $N$, total number of observations $M R_{\exp _{i}}$, experimental moisture ratio values and $M R_{\text {pre }}$, predicted moisture ratio values. These modules have been used by other workers in the literature to evaluate the goodness of fit of different mathematical models. It is generally considered that $\% E$ values below or equal to $10 \%$ give a good fit (Simal et al., 2005).

\section{Moisture Diffusivity}

In the determination of the effective moisture diffusivity $\left(D_{\text {eff }}\right)$, a mathematical model was used based on Fick's second law of diffusion which expresses a relationship between $M R$ and $D_{\text {eff. }}$ The tomato slices are assumed to be in the form of spherical geometry and the Fick's second law of diffusion for spherical object is defined as follow:

$$
\frac{\partial m}{\partial t}=D_{e f f}\left[\frac{\partial^{2} m}{\partial r^{2}}+\frac{2}{r} \frac{\partial m}{\partial r}\right]
$$

Where $m$ can be defined as the moisture content (dry or wet basis), moisture ratio, weight ratio and density. Using the appropriate initial and boundary conditions and assuming the independence of diffusivities and temperature from interior moisture content, negligible volume shrinkage, and discounting the resistance of external convective mass transfer, Crank (1975) gave the analytical solution to Eq. (9) for object with spherical geometry as (Ochoa-Martinez and Ayala-Aponte, 2009):

$$
M R=\frac{6}{\pi^{2}} \sum_{n=1}^{\infty} \frac{1}{n^{2}} \exp \left(\frac{-n^{2} \pi^{2} D_{e f f} t}{r^{2}}\right)
$$

Where $D_{\text {eff }}$ is effective moisture diffusivity $\left(\mathrm{m}^{2} / \mathrm{s}\right), t$, drying time and $r$, radius of the spherical object $(m)$. To be able to determine the $D_{\text {eff }}$, Eq. (10) may be simplified to a linear logarithmic form (Eq. (11)) (Feng, 2000; Agarry et al., 2013):

$$
\ln M R=\ln \left(\frac{6}{\pi^{2}}\right)-\left(\frac{\pi^{2} D_{e f f} t}{r^{2}}\right)
$$

\section{Results and Discussion}

Effect of Pre-treatment and Drying Temperature on Drying Characteristics

The water loss (WL) and weight reduction (WR) of the blanched tomato slices after osmotic pre-treatment is $8 \%$ and $8 \%$, respectively. These values indicated that the blanched tomato slices when immersed in concentrated sodium chloride (salt) solution had lost some quantity of water (moisture) due to osmosis thereby reducing its weight. The water loss after osmotic dehydration indicates that the proposal made for the possibility of pre-treatment is viable (Agarry and Aworanti, 2012). The drying kinetics of blanch-osmotic pre-treated tomato and untreated sliced tomato samples was determined at different bulb temperature under hot air-drying for average moisture contents from $770 \%$ and $830 \%$ dry basis (d.b) to $130 \%$ d.b (kg water/kg dry matter), respectively. Figure 1 shows the dependence of moisture content on drying time for blanch-osmotic pre-treated and untreated sliced tomato samples at temperature of $60^{\circ} \mathrm{C}$. 
The product moisture content variations with drying times as shown in Figure 1 revealed that moisture ratio decreases continuously with drying time for both the blanch-osmotic pre-treated and untreated tomato samples. The product moisture content variations with drying times for both the blanch-osmotic pre-treated and untreated tomato samples at $40,50,70$ and $80^{\circ} \mathrm{C}$ followed the same trend as that of $60^{\circ} \mathrm{C}$ (plots not shown). The continuous decrease in product moisture content for both the pretreated and untreated tomato samples with time indicates that the internal mass transfer for sliced tomato samples was governed by diffusion mechanism. Similar observations have been reported by Doymaz (2007) for tomatoes, Kingsly et al. (2007) for peach, Akpinar and Bicer (2008) for long green pepper, Ismail and Ibn Idriss (2013) for okra, Agarry and Owabor (2012) for banana, and Agarry and Aworanti (2012) for coconut, respectively. Furthermore, the moisture removal was faster for the blanch-osmotic pre-treated tomato slices than for the untreated sample. This observation is due to alteration and disruption in the integrity of the internal structure and subsequent softening of tissues after the combination of blanching and osmotic dehydration pretreatment, which facilitates the transport of moisture to the surface of the product where it is evaporated. A similar observation has been reported for blanched sweet bell-pepper subjected to convective hot air drying (Sharma et al., 2015). In the case of the untreated, there is no cell disruption prior to drying and therefore movement of moisture within the cell is confronted by the resistance mechanisms of intact cell structures. Table 1 shows the values of drying rate and drying time obtained for the drying of untreated and blanch-osmotic pre-treated samples at different drying temperature.
It is seen in Table 1 that the drying rate increased from 22 to $43 \times 10^{-3} \mathrm{~kg} / \mathrm{m}^{2} \mathrm{~h}$ with corresponding decrease in drying time from 16 to $8 \mathrm{~h}$ for untreated sliced tomato samples and from 23 to $52.6 \times 10^{-3} \mathrm{~kg} / \mathrm{m}^{2} \mathrm{~h}$ and a corresponding decrease in drying time from 14 to $6 \mathrm{~h}$ for blanch-osmotic pre-treated tomato samples as the drying temperature increased from 40 to $80^{\circ} \mathrm{C}$. This is in agreement with the observation of Kingsly et al. (2007), Sacilik (2007), Thorat et al. (2010), Agarry and Aworanti (2012), and Purkayastha et al. (2013), respectively, that drying rates increases while drying times decreases with increase in drying temperature. This implies that drying improves with increase in temperature and hence a higher mass transfer (Christie, 1985). Also, as observed from Table 1; at higher drying temperature, the blanch-osmotic pre-treated sliced tomato samples were found to have a higher drying rate and a shorter drying time as compared to the untreated samples. Blanch-osmotic pre-treatment prior to hot air-drying showed that the drying time decreased by $12.5,14.3,16.7,20$ and $25 \%$ at drying temperatures of $40,50,60,70$ and $80^{\circ} \mathrm{C}$, respectively. Consequently, it can be concluded that blanch-osmotic pre-treatment reduced the drying time as a result of increased drying rate. These results are in agreement with the observations of Nieto et al. (2001) and Agarry and Aworanti (2012) whom correspondingly reported that osmotic pre-treatment of mango with increased glucose concentration as well as the osmotic pre-treatment of coconut meat chips with sucrose increased the drying rate during hot air drying. The drying rate curves for blanchosmotic pre-treated sliced tomato samples and the untreated sliced tomato samples at $60^{\circ} \mathrm{C}$ is as shown in Figure 2 .

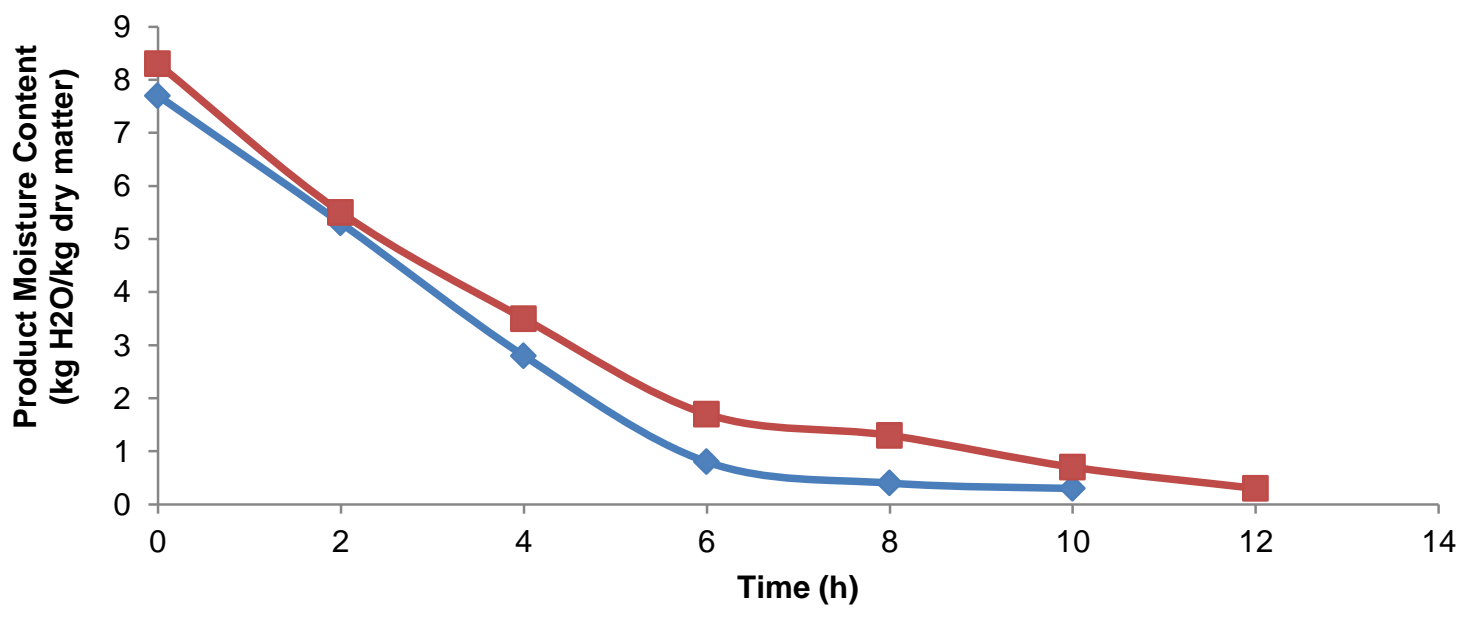

$\sim$ Blanch-Osmotic Pretreated Sample $\quad-\quad$ Untreated Sample

Figure 1 Drying curves of blanch-osmotic pre-treated and untreated sliced tomato samples 


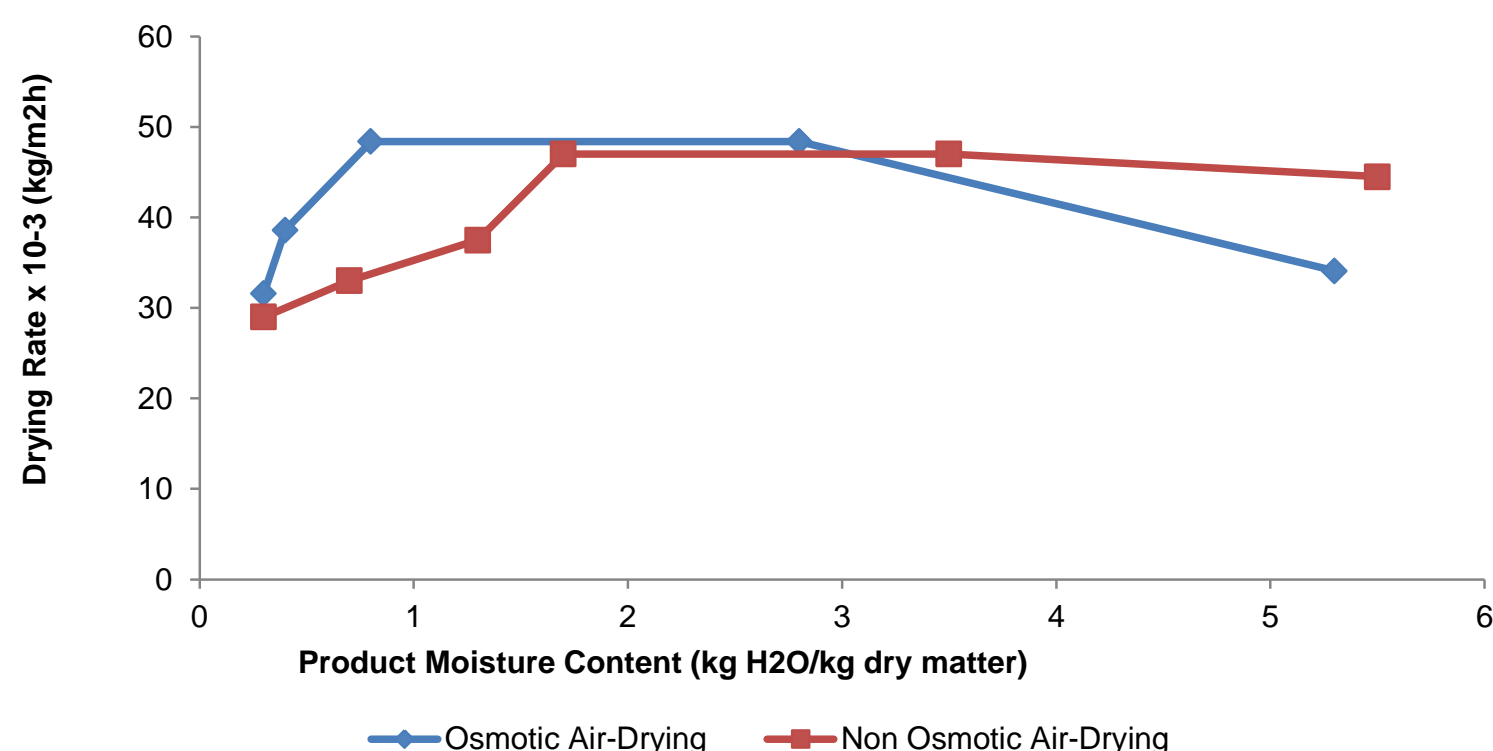

Figure 2 Drying rate curve of blanch-osmotic pre-treated and untreated sliced tomato samples dried at $60^{\circ} \mathrm{C}$

Table 1 Values of drying rate and drying time obtained for untreated and blanch-osmotic pre-treated tomato slices subjected to hot air drying method at different drying temperature

\begin{tabular}{lccc}
\hline Sample & Drying Temperature $\left({ }^{\circ} \mathrm{C}\right)$ & Drying Rate $\left(\times 10^{-3} \mathrm{~kg} / \mathrm{m}^{2} \mathrm{~h}\right)$ & Drying Time $(\mathrm{h})$ \\
\hline \multirow{3}{*}{ Untreated Sample } & 40 & 22 & 16 \\
& 50 & 25 & 14 \\
& 60 & 29 & 12 \\
& 70 & 35 & 10 \\
Pre-treated Sample & 80 & 43.4 & 8 \\
& 40 & 23 & 14 \\
& 50 & 26.3 & 12 \\
& 60 & 31.6 & 8 \\
\hline
\end{tabular}

Figure 2 shows that the rate of moisture removal in both pre-treated and untreated tomato slices was higher in the initial stage, which then decreased as drying progresses. At the initial stage of drying in both pretreated and untreated tomato slices, the available free moisture concentration gradient was higher thereby leading to higher drying rate. That is, the free moisture close to the surface of the product being removed early in the process (Agarry and Aworanti (2012). At high initial moisture content, the initial drying rate is always higher due to higher vapour pressure gradient, which decreases as drying progresses. This observed initial increase in drying may also be as a result of an opening of the physical structure which allows for rapid evaporation and transport of water (Purkayastha et al., 2013). The initial drying rate was highest for the untreated sample as a result of its higher initial moisture content (830\% d.b) which was lower in the blanch-osmotic pre-treated samples $(770 \%$ d.b). In addition, the drying rate curve at $60^{\circ} \mathrm{C}$ indicated that the product moisture content of blanch-osmotic pre-treated and untreated sliced tomato samples varies constantly with the rate of drying (constant rate period) followed by a decrease in the drying rate which varies linearly (falling rate period) with product moisture content. This behaviour reveals that the drying of tomato is both in the constant and falling rates period. Thus, it suggests that the mechanisms of moisture removal are temperature, capillary and diffusion control; hence, tomato is a hygroscopic food material (Arumuganathan et al., 2009; Purkayastha et al., 2013). However, Purkayastha et al. (2013) observed two falling rates period and no constant rate period in the drying behavior of blanched tomato.

Effect of Pre-treatment and Drying Temperature on Nutritional Value

The nutritional value (in terms of vitamin $\mathrm{C}$ (ascorbic acid)) of blanch-osmotic pre-treated and untreated sliced tomato samples in relation to drying temperature is as shown in Figure 3. The vitamin $\mathrm{C}$ content of fresh tomato was about $0.054 \%$, and this value generally decreased as drying temperature increased during the hot air-drying of blanch-osmotic pre-treated and untreated tomato slices (Figure 3). That is, the percentage vitamin $\mathrm{C}$ content for both the untreated and blanch-osmotic pre-treated tomato samples dried at $40,50,60,70$, and $80^{\circ} \mathrm{C}$ was 
respectively less than the percentage vitamin $\mathrm{C}$ content for the fresh tomato $(0.054 \%)$ prior to pre-treatment and drying. Similar observations have been reported for blanched tomato slices (Purkayastha et al., 2013) and blanched cocoyam slices (Afolabi et al., 2015). This indicates that both hot air drying and osmotic agent had a considerable effect on the nutritional value. The retention of vitamin $\mathrm{C}$ content in blanch-osmotic pre-treated tomato slices dried at 40, 50, 60, 70, and $80^{\circ} \mathrm{C}$ was correspondingly $43 \%, 54 \%, 61 \%, 57 \%$ and $39 \%$, respectively. Therefore, the highest reduction in vitamin $\mathrm{C}$ content occurred at $80^{\circ} \mathrm{C}(61 \%)$ and lowest at $60^{\circ} \mathrm{C}$ (39\%). On the other hand, the retention of vitamin $\mathrm{C}$ content in untreated tomato slices dried at 40, 50, 60, 70, and $80^{\circ} \mathrm{C}$ was correspondingly $72 \%, 78 \%, 94.5 \%, 90.7 \%$ and $57.4 \%$, respectively. Also, the highest reduction in vitamin $\mathrm{C}$ content occurred at $80^{\circ} \mathrm{C}(42.6 \%)$ and lowest at $60^{\circ} \mathrm{C}(5.5 \%)$. Thus, these observations indicate that tomato slices pre-treated or untreated, dried at $60^{\circ} \mathrm{C}$ were able to retain the heat-labile vitamin $\mathrm{C}$ better. Moreover, the hot air-drying of blanch-osmotic pre-treated tomato slices produced a dried tomato product with lower percentage vitamin $\mathrm{C}$ retention than the dried tomato product produced by hot air-drying of untreated tomato slices. This suggest that the concentrated salt solution being a strong electrolyte resulted in the leaching of the nutrients and hence solubilization thereby enhancing the loss of vitamin C. Gupta et al. (2014) have also reported that vitamin $\mathrm{C}$ loss in blanched pre-treated aonla shreds subjected to hot air-drying between 50 and $60^{\circ} \mathrm{C}$ was higher in comparison with the vitamin $\mathrm{C}$ loss in untreated aonla shreds.

\section{Optimization of Drying Temperature}

As shown in the preceding Table 1, sliced tomato samples dried at lower temperature took a longer drying time to achieve a product with moisture content of $130 \%$ d.b thereby given room for longer heat exposure. As a result of this longer heat exposure, vitamin $\mathrm{C}$ (nutritional constituent) which is heat sensitive reduced in percentage value as shown in Figure 3. The sliced tomato samples subjected to higher temperature $\left(70\right.$ and $\left.80^{\circ} \mathrm{C}\right)$ of drying took shorter drying time to attain product moisture content of $130 \%$ d.b; however, because of its exposure to greater heat effect there was greater reduction in the vitamin $\mathrm{C}$ percentage value. Therefore, given the fact that in most drying operations which employ heat, the major objective is to expel all the free moisture (bound and unbound moisture) within the shortest possible time without necessarily destroying the texture, colour, flavour and nutritional value, hence a compromise must be made between the maximum drying rate and the maintenance of food quality. It could be observed from the above Figure 3 , that the percentage vitamin $\mathrm{C}$ retention in dried tomato products produced by the hot air-drying of blanchosmotic pre-treated tomato slices as well as the untreated tomato slices respectively increased as the drying temperature increased from 40 to $60^{\circ} \mathrm{C}$, and above $60^{\circ} \mathrm{C}$ it decreased to a value much lower than its value for fresh tomato prior to drying. Thus, it would perhaps be right to imply that the optimum drying temperature for tomato is $60^{\circ} \mathrm{C}$, since at this temperature the percentage vitamin $\mathrm{C}$ retention is optimum as it is relatively close to its value for fresh tomato prior to pre-treatment and drying. Purkayastha et al. (2013) in their study of the thin layer drying of tomato have reported that optimum retention of ascorbic acid was achieved in tomato slices dried at $50^{\circ} \mathrm{C}$ and there was a considerable decrease in nutrient for those dried at higher temperature of 65 and $70^{\circ} \mathrm{C}$.

\section{Modeling the Drying Kinetics of Tomato}

Experimental results of moisture variation with drying time were fitted to four different drying models (Eqs. (5)(8)) and the fits are not shown. The models parameters were determined using the non-linear regression tool of MATLAB 7.0 computer software package. The drying model which depicted the highest coefficient of determination $\left(R^{2}\right)$ as well as the lowest root mean square error (RMSE) was selected. The $R^{2}$ and $R M S E$ values obtained through the non-linear regression analysis are summarized in Table 2 for untreated and blanch-osmotic pre-treated tomato samples subjected to hot air drying method.

Table 2 The different drying models goodness of fit for untreated and blanch-osmotic pre-treated tomato slices subjected to hot air drying method

\begin{tabular}{clccc}
\hline Sample & \multicolumn{1}{c}{ Model } & Drying Temperature $\left({ }^{\circ} \mathrm{C}\right)$ & $\mathrm{R}^{2}$ & RMSE \\
\hline \multirow{3}{*}{ Untreated Sample } & Newton & 60 & 0.9938 & 0.0278 \\
& Page & 60 & 0.9975 & 0.0195 \\
& Henderson \& Pabis & 60 & 0.9943 & 0.0292 \\
& Logarithmic & 60 & 0.9963 & 0.0262 \\
\hline \multirow{5}{*}{ Pre-treated Sample } & Newton & 60 & 0.9678 & 0.0709 \\
& Page & 60 & 0.9972 & 0.0235 \\
& Henderson \& Pabis & 60 & 0.9705 & 0.0759 \\
& Logarithmic & 60 & 0.9825 & 0.0674 \\
\hline
\end{tabular}

Table 3 Values of effective moisture diffusivity for untreated and blanch-osmotic pre-treated tomato slices subjected to hot air-drying at $60^{\circ} \mathrm{C}$

\begin{tabular}{llll}
\hline \multicolumn{1}{c}{ Sample } & Temperature $\left({ }^{\circ} \mathrm{C}\right)$ & Effective moisture diffusivity $\left(\mathrm{D}_{\text {eff }} \times 10^{-11}\right)\left(\mathrm{m}^{2} / \mathrm{s}\right)$ & $\mathrm{R}^{2}$ \\
\hline Untreated Sample & 60 & 4.43 & 0.9856 \\
Pre-treated Sample & 60 & 6.33 & 0.9684 \\
\hline
\end{tabular}




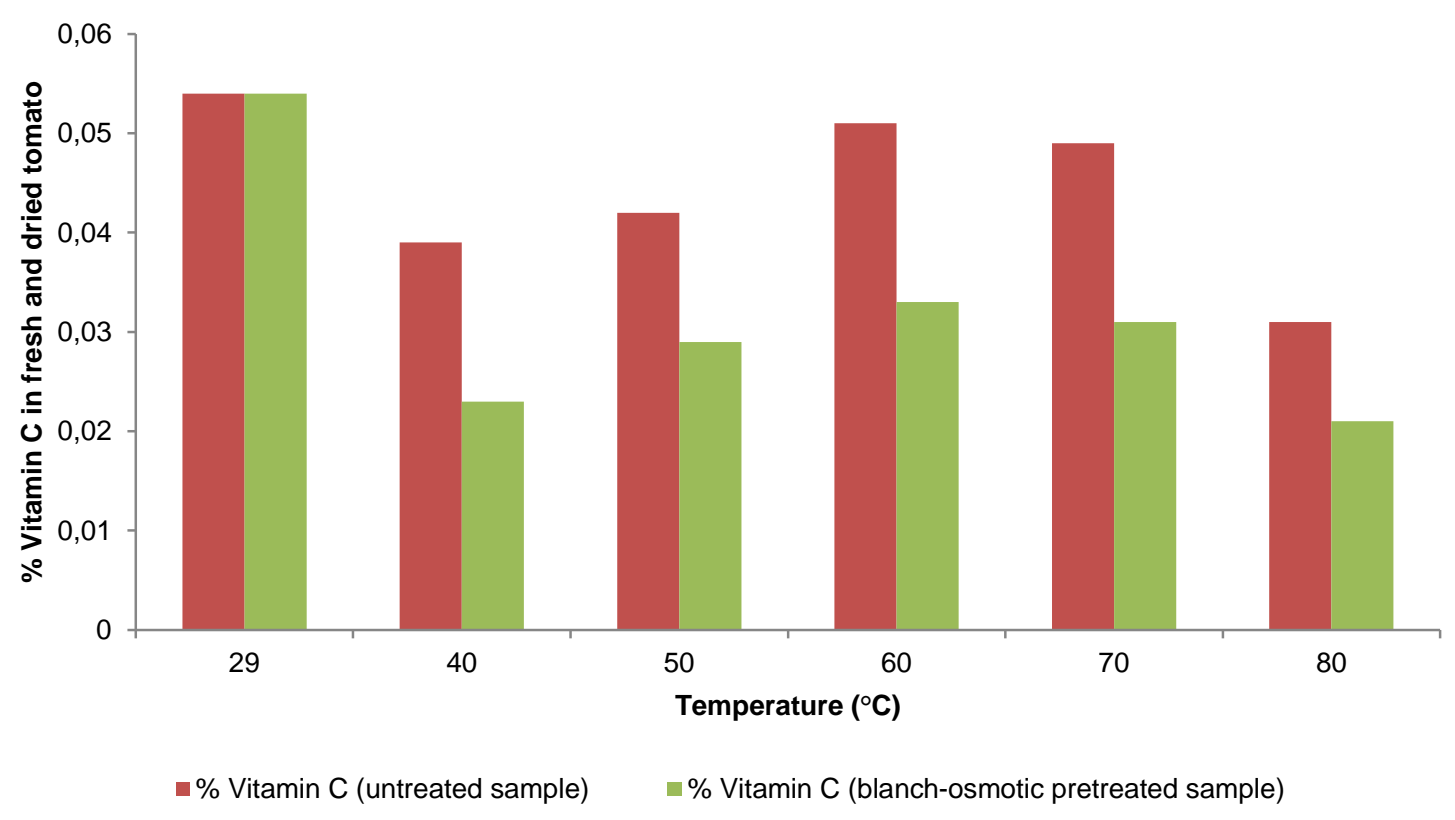

Figure 3 The nutritional vitamin $\mathrm{C}$ value of blanch-osmotic pre-treated and untreated sliced tomato samples dried at different temperature under hot air-drying

(a) Untreated Sample

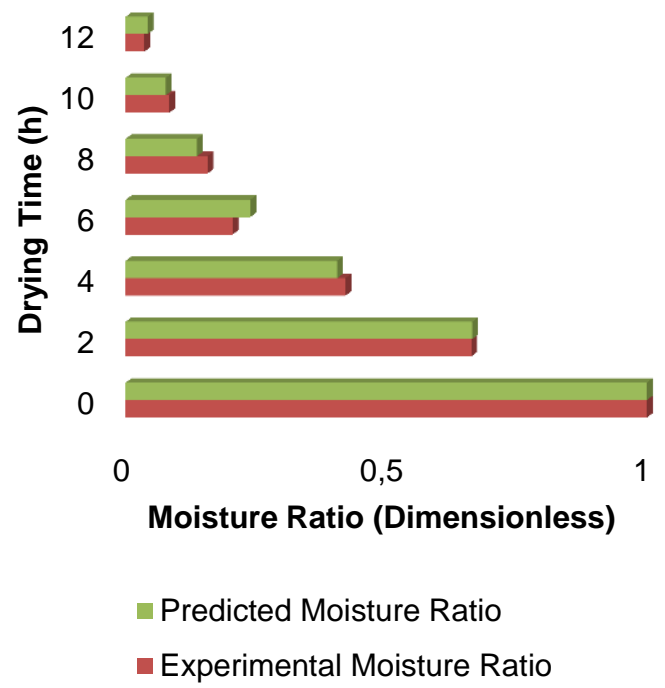

(b) Preated Sample

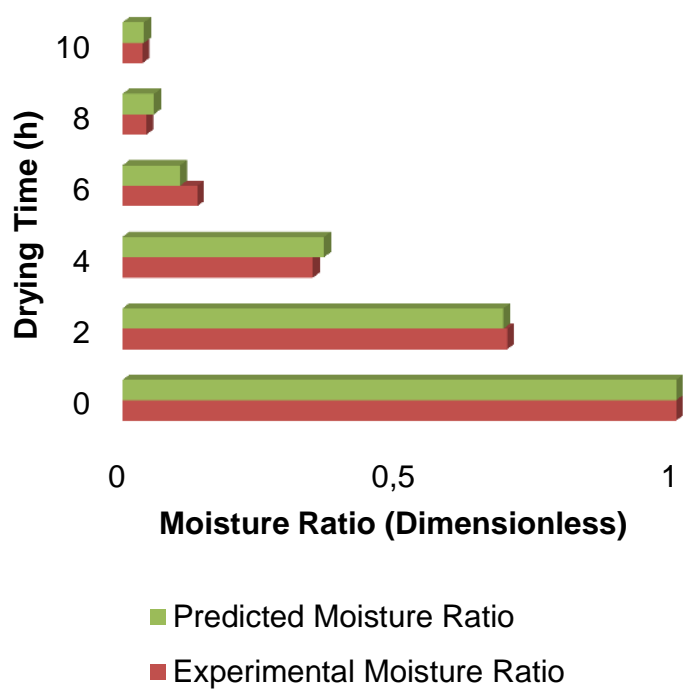

Figure 4 Representation of predicted moisture ratio versus experimental moisture ratio for untreated and blanch-osmotic pre-treated tomato slices under hot air-drying at $60^{\circ} \mathrm{C}$

The results presented in Table 2 show that at drying temperature of $60^{\circ} \mathrm{C}$, the $R^{2}$ value was greater than 0.90 , which indicates a good fit (Kingsly et al., 2007; Agarry and Aworanti, 2012) of all the four drying models to the tomato drying kinetics data. However, the value of $R^{2}$ for the Page model in comparison with the other models was the highest and with the lowest value of RMSE. Thus, the Page model may be proposed to be the best model to describe the drying kinetics of tomato. Similar findings have been reported for hot air drying of red pepper, tomato and potato (Akpinar et al., 2003; Simal et al.,
2005; Doymaz, 2007). However, Sacilik (2007) and Purkayastha et al. (2013) had respectively observed in their different study of thin layer drying of tomato that Logarithmic model best described the drying characteristics of blanched and untreated tomato. The accuracy of the Page model to simulate the drying curves of untreated and blanch-osmotic pre-treated tomato slices under hot air-drying at $60^{\circ} \mathrm{C}$ was respectively evaluated. To mathematically evaluate the simulation, the average relative error $(\% E)$ and coefficient of determination $\left(R^{2}\right)$ were calculated from comparing the experimental 
moisture ratio and those given by the proposed model for the range of drying temperature considered. The estimated kinetic parameter values for the Page model are presented as follows: $k$ and $n$ values for the untreated tomato sample are 0.1847 and 1.143 , respectively with $\left(R^{2}=0.9975\right.$ and $\% E=1.24)$; while for the pre-treated tomato sample it is 0.1239 and 1.554 with $\left(R^{2}=0.9972\right.$ and $\left.\% E=11.4\right)$. It is observed that the $R^{2}$ values are high and the $\% E$ values are relatively low for the sliced tomato samples dried at $60^{\circ} \mathrm{C}$. Thus, the Page model has allowed an accurate simulation of the drying curves of untreated and blanchosmotic pre-treated tomato slices for the temperature studied under hot air-drying; thereby, exhibiting a high agreement between experimental and predicted (estimated) moisture ratio as shown in Figure 4.

The result also showed that the drying kinetics of untreated tomato slices described by Page model, the drying constant ' $k$ ' is higher than the ' $k$ ' value for blanchosmotic pre-treated tomato slices; while the empirical constant ' $n$ ' is lower than the value of ' $n$ ' for blanchosmotic pre-treated tomato slices under hot air-drying.

\section{Moisture Diffusivity}

The transfer of water (moisture transport) during hot air-drying of untreated and blanch-osmotic pre-treated tomato slices was described by the application of Fick's diffusion model. The drying curves experimentally obtained at $60^{\circ} \mathrm{C}$ were fitted to the Fick's diffusion equation (Eq. (13)). The good linear fitting to this equation with coefficient of determination $\left(R^{2}\right)$ ranging from $96-98 \%$ for the drying process showed that drying of tomato is well represented by the Fick's diffusion model and thus allowed for the calculation of the effective moisture diffusivity $\left(D_{\text {eff }}\right)$ at $60^{\circ} \mathrm{C}$. The $D_{\text {eff }}$ obtained for blanch-osmotic pre-treated tomato slices was $4.43 \times 10^{-11}$ $\mathrm{m}^{2} / \mathrm{s}\left(R^{2}=0.9856\right)$ and $6.33 \times 10^{-11} \mathrm{~m}^{2} / \mathrm{s}\left(R^{2}=0.9684\right)$ for untreated tomato slices dried at $60^{\circ} \mathrm{C}$, respectively, as presented in Table 3 . These values are within the general range of $10^{-11}$ to $10^{-9} \mathrm{~m}^{2} / \mathrm{s}$ for drying of food materials (Doymaz, 2007; Honore et al., 2014). The results in Table 3 revealed that $D_{\text {eff }}$ was comparatively higher for blanchosmotic pre-treated tomato slices than that for untreated tomato slices. However, the $D_{\text {eff }}$ values obtained for pretreated and untreated tomato slices in this present study are lower than those estimated by different authors for tomatoes: $3.72-12.27 \times 10^{-9} \mathrm{~m}^{2} / \mathrm{s}$ for tomatoes dried at $45-75^{\circ} \mathrm{C}$ (Akanbi et al., 2006); $4.28-6.28 \times 10^{-9} \mathrm{~m}^{2} / \mathrm{s}$ for blanched tomatoes dried at $50-70^{\circ} \mathrm{C}$ (Sacilik, 2007) and $2.387 \times 10^{-9} \mathrm{~m}^{2} / \mathrm{s}$ for blanched tomato dried at $60^{\circ} \mathrm{C}$ (Purkayastha et al., 2013).

\section{Conclusion}

From the results of the studies on the drying of untreated and blanch-osmotic pre-treated tomato sample using hot air-drying, it can be concluded that drying rate is proportional to drying temperature and inversely proportional to drying time under hot air-drying. The drying time required to attain a final product moisture content of $130 \%$ d.b for both untreated and blanch- osmotic pre-treated tomato slices decreased with increase in temperature. The drying of tomato is both in constant rate and falling rate period, hence they are hygroscopic and thus behave like porous solids. Pre-treatment and drying temperature has a significant effect on the drying kinetics and nutritional quality of tomato. Blanch-osmotic pre-treatment prior to hot air drying offers a higher drying rate and faster drying time than non-pre-treatment. Pretreatment using sodium chloride of high concentration as osmotic agent suggests having a more damaging impact on the nutritional constituents than non-pre-treatment. Nutritional constituents (such as vitamin C) of tomato (vegetables) are both heat (i.e. temperature) and osmotic agent sensitive. The optimum drying temperature for tomato (and probably for vegetables) may be suggested to be $60^{\circ} \mathrm{C}$. The use of the semi empirical Page model allowed for sufficient description of the drying curves of untreated and blanch-osmotic pre-treated tomato slices under hot air drying which could represent a useful tool for engineering purposes. The Fick's diffusion model presented a good linear adjustment to the experimental drying results obtained for both untreated and blanchosmotic pre-treated tomato slices under hot air drying which allowed the estimation of the effective moisture diffusivity. The estimated effective moisture diffusivities ranged from 4.43 to $6.33 \times 10^{-11} \mathrm{~m}^{2} / \mathrm{s}$ for untreated and blanch-osmotic pre-treated tomato slices dried at $60^{\circ} \mathrm{C}$ under hot air drying, respectively.

\section{References}

Afolabi TJ, Tunde-Akintunde TY, Adeyanju JA. 2015. Mathematical modeling of drying kinetics of untreated and pretreated cocoyam slices. J. Food Sci. Technol., 52 (5): 2731 2740.

Agarry SE, Owabor CN. 2012. Modelling of the drying kinetics of banana under natural convection and forced air drying. Journal of Nigerian Society of Chemical Engineers 27 (1): 101 - 115.

Agarry SE, Aworanti OA. 2012. Modelling the drying characteristics of osmosised coconut strips at constant air temperature. J. Food Proc. Technol., 3:151.

Agarry SE, Ajani AO, Aremu MO. 2013. Thin layer drying kinetics of pineapple: effects of blanching temperature-time combination. Nigerian J. Basic and Appl. Sci., 21 (1): 1 - 10.

Agarry SE, Durojaiye AO, Afolabi TJ. 2005. Effect of Pre-treatment on the drying rates and drying time of potato. Journal of Food Technology 3(3): $361-364$.

Agarry SE, Yusuf RO, Owabor CN. 2006. Studies on air-dry processing of onions (Alium cepa). J. Food Technol. 4(4): 357361.

Akanbi CT, Adeyemi RS, Ojo A. 2006. Drying characteristics and sorption isotherm of tomato slices. J. Food Eng., 73:141-146

Akonor PT, Tortoe C. 2014. Effect of blanching and osmotic pretreatment on drying kinetics, shrinkage and rehydration of chayote (sechium edule) during convective drying. British J. Appl. Sci. \& Technol. 4(8): 1215-1229.

Akpinar E, Midilli A, Bicer Y. 2003. Single layer drying behavior of potato slices in a convective cyclone dryer and mathematical modeling. Energy Conversion Management 44: 1689 - 1705.

Akpinar EK, Bicer Y. 2008. Mathematical modeling of thin layer drying process of long green pepper in solar dryer and under open sun. Energy Conversion and Management 49: 1367-1375.

Alzamora SM, Chirife J. 1980. Some factors controlling the kinetics of moisture movement during avocado dehydration. Journal of Food Science 45: 1649-1657. 
Ando Y, Mizutani K, Wakatsuki N. 2013. Effect of blanching and freeze-thaw on the drying rate and electrical impedance characteristics of carrots. $4^{\text {th }}$ International Conference on Food Engineering and Biotechnology. IACSIT Press, Singapore. DOI:10.7763/IPCBEE.2013.v50.9.

Arumuganathan T, Manikantan MR, Rai RD, Anandakumar S, Khare V. 2009. Mathematical modeling of drying kinetics of milky mushroom in a fluidized bed dryer. Int Agrophys 23:1-7

Association of Official Analytical Chemists, 1995. Official Methods of Analysis, $15^{\text {th }}$ edition, AOAC, 930.06, Arlington, Va. USA.

Christie JG. 1985. Transport process and unit operations, $6^{\text {th }}$ edition, Allyn and Bacon.

Crank J. 1975. The mathematics of diffusion, $2^{\text {nd }}$ ed., Oxford, London.

Dandamrongrak R, Mason R, Young G. 2003. The effect of pretreatments on the drying rate and quality of dried bananas. International Journal of Food science and Technology 38: 877882 .

Demir V, Gunhan T, Yagcioglu AK, Degirmencioglu A. 2004 Mathematical modeling and the determination of some quality parameters of air-dried bay leaves. Biosystem Engineering 88: $325-335$.

Doymaz I. 2004. Effect of pre-treatments using potassium metabisulphite and alkaline ethyl oleate on the drying kinetics of apricots. Biosystem Engineering 89: 281-287.

Doymaz I. 2007. Air-drying characteristics of tomatoes. Journal of Food Engineering, 78 (4): 1291 - 1297.

Doymaz I. 2010. Effect of citric acid and blanching pre-treatments on drying and rehydration of Amasya red apples. Food Bioproduction Processing 88(2-3):124-132.

Doymaz I. 2014. Effect of blanching temperature and dipping time of broccoli. Food Science and Technology International 20 (2): 149-157.

Feng H, Tang J, Dixon-Warren I. 2000. Determination of moisture diffusivity of red delicious apple tissues by thermogravimetric analysis. Drying Technology 18 (6): 1183 -1199.

Gupta RK, Sharma A, Kumar P, Vishwakarma RK, Patil RT. 2014. Effect of blanching on thin layer drying kinetics of aonla (Emblica officinalis) shreds. Journal of Food Science and Technology 51 (7): 1294-301.

Honoré O, François Z, Raguilignaba S, Aboubacar T, Hélène D. 2014. Characterization of Okra Convective Drying, Influence of Maturity. Food and Nutrition Sciences 5: 590-597.

Ismail MA, Ibn Idriss EM. 2013. Mathematical modelling of thin layer solar drying of whole okra (Abelmoschosus esculentus (L.). Moench) pods. International Food Research Journal 20 (4): $1983-1989$.

Khawas P, Das AJ, Dash KK, Deka SC. 2014. Thin-layer drying characteristics of Kachkal banana peel (Musa ABB) of Assam, India. International Food Research Journal 21 (3): 975 - 982.
Kingsly RP, Goyal RJ, Manikantan MR, Ilyas SM. 2007. Effects of pretreatments and drying air temperature on drying behaviour of peach slice. International Journal of Food science and Technology 42: 65 -69.

Nieto A, Castro MA, Alzamora SM. 2001. Kinetics of moisture transfer during air drying of blanched and/or osmotically dehydrated mango. Journal of Food Engineering 50: 175-185.

Ochoa-Marinez CI, Ayala-Aponte AA. 2009. Suitability of Crank's solution to Ficks second law for water diffusivity calculation and moisture loss prediction in osmotic dehydration of fruits. Journal of Food Process Engineering 32 (6): 933 - 943.

Ozen BF, Dock LL, Ozdemir M, Floros JD. 2002. Processing factors affecting the osmotic dehydration of diced green peppers. International Journal of Food science and Technology 37: 497-502.

Purkayastha MD, Nath A, Deka BC, Mahanta CL. 2013. Thin layer drying of tomato slices. Journal of Food Science and Technology 50(4): 642-653.

Ranganna S. 1986. Handbook of analysis and quality control for fruit and vegetable products. McGraw Hill Publishing Co. Ltd, New Delhi

Sacilik K. 2007. The thin-layer modelling of tomato drying process. Agriculturae Conspectus Scientifi cus 72 (4): 343-349.

Sankat CK, Castaigne F, Maharaj R. 1996. The air drying behaviour of fresh and osmotically dehydrated banana slices. International Journal of Food science and Technology 31: 123-135.

Simal S, Garau C, Femenia, A, Rossello C. 2005. Drying of red pepper (Capsicum annum): water desorption and quality. International Journal of Food Engineering 1(4): 1 -14.

Sharma R, Joshi VK, Kaushal M. 2015. Effect of Pre-treatment and drying methods on quality attributes of sweet bell-pepper (Capsilum annum) powder. Journal of Food Science and Technology 52 (6): 3433-3439.

Thorat ID, Mohapatra D, Sutar RF, Kapdi SS, Jagtap DD. 2010. Mathematical Modeling and Experimental Study on Thin Layer Vacuum Drying of Ginger (Zingiber officinale R.) slices. Food Bioprocess Technol. doi:10.1007/s11947-010-0429-y

Tunde-Akintunde TY, Ogunlakin GO. 2013. Mathematical modeling of drying of pre-treated and untreated pumpkin. Journal of Food Science and Technology 50(4): 705-713.

Vega-Galvez A, Lara E, Flores V, Di Scala K, Lemus-Mondaca R. 2012. Effect of selected pretreatments on convective drying process of blueberries (var. O'neil). Food and Bioprocess Technology 5 (7): 2797-2804.

Waewsak J, Chindaruksa S, Punlek C. 2006. A mathematical modeling study of hot air drying for some agricultural products. Thammasat International Journal of Science and Technology 11: $14-20$. 